\title{
THE EFFECTS OF TARAXACUM OFFICINALE EXTRACTS (TOE) SUPPLEMENTATION ON PHYSICAL FATIGUE IN MICE
}

\section{Zhang Jinchun* and Chen Jie}

Department of Physical Education, Huangshi Institute of Technology, Huangshi, Hubei Province, 435003, PRC

*E-Mail: jinchunzh@yahoo.cn, ChenJie CJ@126.com

\begin{abstract}
The study is to investigate the effectof Taraxacum officinale extracts (TOE) supplementation on physical fatigue based on the forced swimming capacity in mice. Forty Kunming male mice were randomly divided into 4 groups, i.e., normal control (NC) and three doses of TOE treated group (High-dose, Middle-dose and Low-dose). Three TOE treated groups were treated by oral TOE with 10,30 and $100 \mathrm{mg} / \mathrm{kg}$ b.w respectively for a period of 42 days. The normal control group was given a corresponding volume of sterile distilled water. After 6 weeks, the forced swimming capacity and blood biochemical parameters in mice were measured, and the result showed that TOE had an anti- physical fatigue effect. It enhanced the maximum swimming capacity of mice, effectively delayed the lowering of glucose in the blood, and prevented the increase in lactate and triglyceride concentrations.
\end{abstract}

Key Words: Taraxacum officinale extracts, forced swimming capacity, mice

\section{Introduction}

Fatigue is a common symptom both in sickness and in health (Abe at al., 1995; Babcock et al., 1995; Borer et al., 2009; Ream and Richardson,1997). It can be subdivided into physical and mental fatigue. In China, Traditional Chinese Medicine (TCM) has a long history of use as 'tonics' to treat physical fatigue and are now being validated by scientific approach for their remarkable healing potential.

Taraxacum officinale (TO), a member of the Asteraceae family, is widespread throughout the warm-temperate zones of the Northern Hemisphere and have been used in many traditional and modern herbal medical systems, as have been documented particularly in Asia and Europe (Kim et al., 2000; Shen et al., 2004; Koo et al., 2004; Seo et al., 2005; Sigstedt et al., 2008; Zhang et al., 2008). In traditional Chinese medicine (TCM), it is also acclaimed as a nontoxic herb with exceptional values for its choleretic, diuretic, anti-rheumatic, and anti-inflammatory properties (Lin and Zheng, 1998; Hu and Kitts, 2003; Jeon et al., 2008). Several flavonoids including caffeic acid, chlorogenic acid, ferulic acid, luteolin, and luteolin 7-glucoside have been isolated from the Taraxacum officinale (Williams et al., 1996 ; Shen et al., 2004; Schütz et al., 2005; Shen et al., 2006; Xu and Xu, 2008). However, relatively less has been studied about the effect of Taraxacum officinale on physical fatigue. The aim of the present study is to examine the effectof Taraxacum officinale on physical fatigue, based on the forced swimming capacity of mice administered Taraxacum officinale extracts (TOE).

\section{Materials and Methods}

Plant materials and preparation of extracts 
Plant materials of Taraxacum officinale were obtained from local herb stores in Huangshi City. Voucher specimen of the plant materials (voucher No. 07214) were deposited at the Herbarium at the Huangshi Institute of Technology. Taraxacum officinale extracts (TOE) were prepared by decocting the dried prescription of herbs with boiling distilled water. The decoction time was about $3 \mathrm{hr}$ (Ling et al., 2005; Wu et al., 2005; Su et al., 2008).

\section{Preparation of animal}

Four-week-old Kunming male mice weighing 18-22 g were procured from Huangshi Laboratory Animal Center (Huangshi, China) and used for experiments after one week of acclimatization. Animals were housed in an air conditioned room (22 - $24{ }^{\circ} \mathrm{C}$ with a $12 \mathrm{hr}$ light cycle) and maintained according to the Guide for the Care and Use of Laboratory Animals established by Huangshi Institute of Technology (Huangshi, China). The water and diet were provided ad-libitum.

\section{Grouping of animals}

For the measurement of the forced swimming capacity and analysis of blood biochemical parameters in mice, forty Kunming male mice were randomly divided into 4 groups(, i.e.,normal control (NC) and three doses of TOE treated group (Tables 1). The volume of administration was $1 \mathrm{~mL}$ and the treatments lasted for 42 days. Each mice was subjected to swimming exercise 15 -mins period daily for the 6 weeks.

Tables 1: Grouping of animals

$\begin{array}{lll}\text { Group } & \text { Number } & \text { Administration of animals } \\ \text { Normal control (NC) } & 10 & \text { The mice were treated by oral sterile distilled water. } \\ \text { Low-dose (LD) } & 10 & \text { The mice were treated by oral TOE with } 10 \mathrm{mg} / \mathrm{kg} \text { b.w } \\ \text { Middle-dose (MD) } & 10 & \text { The mice were treated by oral TOE with } 30 \mathrm{mg} / \mathrm{kg} \text { b.w } \\ \text { High-dose (HD) } & 10 & \text { The mice were treated by oral TOE with } 100 \mathrm{mg} / \mathrm{kg} \text { b.w }\end{array}$

\section{Measurement of the forced swimming capacity}

After 6 weeks, the forced swimming capacity in mice was measured with swimming tank $(90 \times 45 \times 45 \mathrm{~cm})$ filled with fresh water to a depth of $30 \mathrm{~cm}$. Water temperature was maintained at $30 \pm 1{ }^{\circ} \mathrm{C}$. A lead block ( $10 \%$ of body weight) was loaded on the tail root of the mice. Exhaustion was determined by observing loss of coordinated movements and failure to return to the surface within 5 s (Jung et al., 2004; Shin et al., 2006; Sugino et al., 2007; Nozawa et al., 2009). Swimming time was recorded as minute for each mice.

\section{Analysis of blood biochemical parameters}

Blood samples were taken by capillary glass tubes from the eye venous pool of mice after light anesthetized with ether, and the serum was separated for the measurement of triglyceride, glucose and lactate levels. Then blood triglyceride, glucose and lactate concentrations were determined according to the recommended procedures provided by the commercial diagnostic kit (Sigma Co., Shanghai, China).

\section{Statistical analyses}

All data were reported as means standard deviation (SD). Statistical analysis was performed by Kruskal Wallis Varyans Analysis followed by a post-hoc Mann-Whitney U test. The level of $p<0.05$ was taken to indicate statistical significance. All statistical analyses were performed using computer software package (SPSS for Windows 13.0). 


\section{Results and Discussion}

Effect of TOE on the body weight of mice

Figure 1 showed the body weight change of the mice during the experimental period. The body weight of all experimental animals was similiar initially. However, all groups gained weight by the end of the experiment. At the 6 th week, middle-dose (MD) group body weight increased the most by all the other groups while normal control group increased the least. However, there was no statistical difference between each TOE treated group and normal control (NC) group (p > 0.05). So the TOE had no significant effect on the body weight.

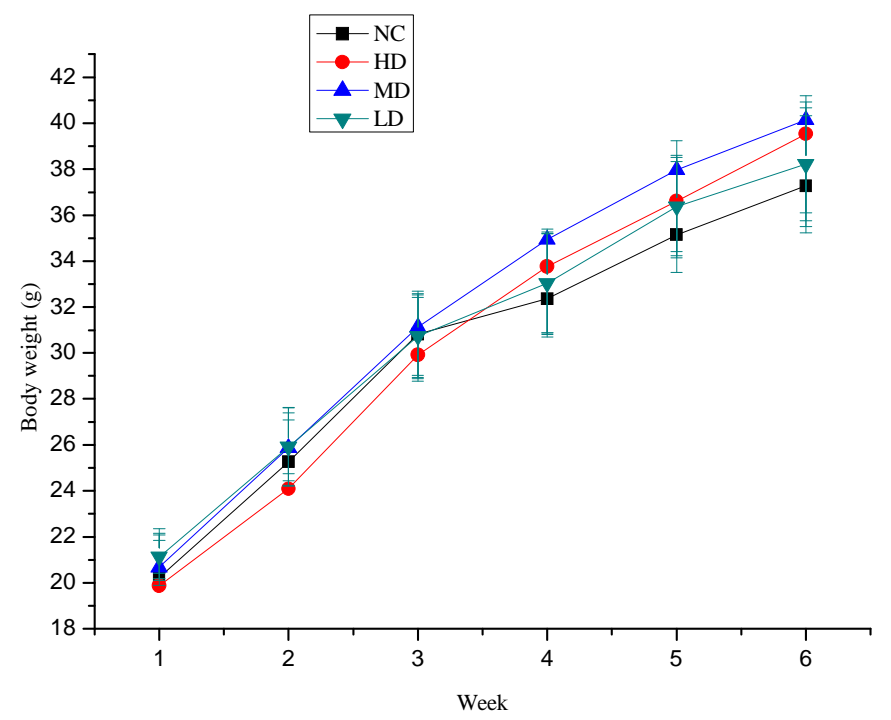

Figure 1: Effect of TOE on the body weight of mice. Each value represents mean $\pm \mathrm{SD} ; \mathrm{n}=10$.

\section{Effect of TOE on the forced swimming capacity in mice}

The forced swimming capacities are shown in Figure 2. There are significant differences in the swimming time to exhaustion between the normal control (NC) group and each TOE treated group $(\mathrm{p}<0.05)$.

Swimming is frequently preferred as an exercise model for small laboratory animals, and it has several advantages over other types of exercise (Kramer et al., 1993; Yalcin et al., 2000). In this study, the forced swimming capacity test in mice was employed to evaluate the effectof medicinal plant extracts on exercise durability of mice. The data of the present study showed that the swimming time to exhaustion of the all TOE treated groups were significantly longer than that of the normal control (NC) group. The result indicated that TOE enhanced the swimming capacity by lessening of physical fatigue in mice.

\section{Effect of TOE on the blood biochemical parameters}

Blood biochemical parameters were shown in Table 1. Muscular work, performed aerobically in the post-absorptive state, depends mainly on the utilization of fat. Free fatty acids and triglyceride fatty acids can provide energy 
for muscular contraction (Jones and Havel, 1967; Jung et al., 2004; Fueger et al., 2007). In this study, blood triglyceride concentrations were lower in all TOE treated groups than in the normal control (NC) group ( $<<0.05)$. The result suggested that TOE could increase fat utilization of mice during exercise, delaying the onset of fatigue.

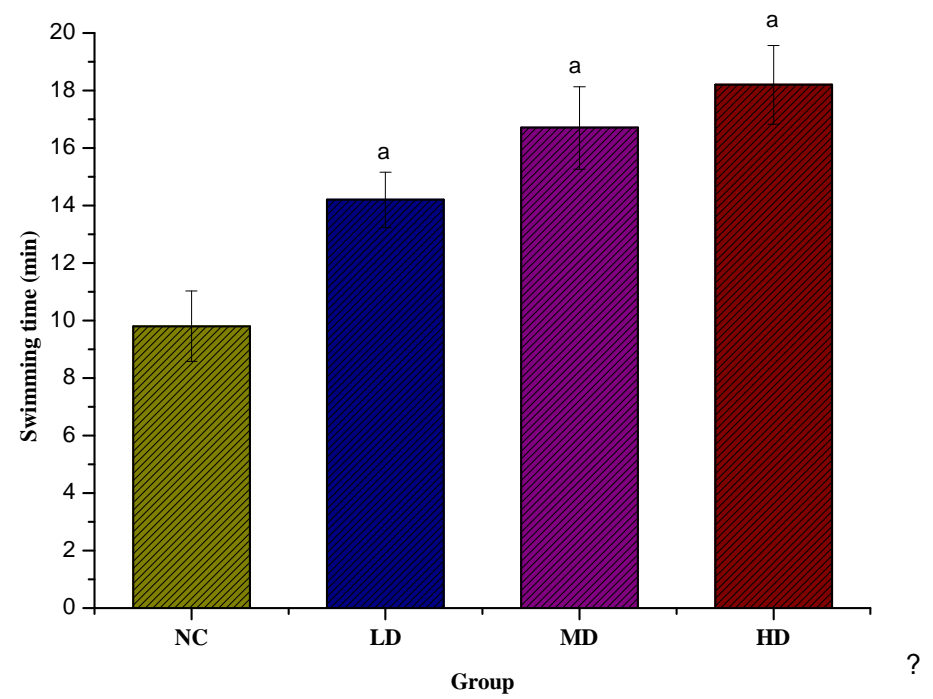

Figure 2: Effect of TOE on the forced swimming capacity in mice

Each value represents mean $\pm \mathrm{SD} ; \mathrm{n}=10$. ${ }^{\mathrm{a}} \mathrm{p}<0.05$, compared with normal control group.

It was known that hypoglycemia could suppress the active functioning of the brain during exercise, and this often led to the inability of continuing exercise (Wang et al., 2006; Borer et al., 2009). On the other hand, the homeostasis of blood glucose played an important role in prolonging endurance exercise (Van der Vusse and Saris, 1991; Zinker et al., 1993; Abe et al., 1995). In this study, blood glucose concentrations were significantly higher in all TOE treated groups than in the normal control (NC) group ( $<$ 0.05). The result indicated that the supply of glucose could be used smoothly and /or that glucose utilization might decrease by the use of TOE as an energy source during exercise.

Blood lactate is the glycolysis product of carbohydrate under an anaerobic condition and glycolysis is the main energy source for fierce exercise in a short time. It represents the degree of fatigue after exercise and the condition of recovery (Babcock et al., 1995; Wang et al., 2006; Yu et al., 2008; Cao et al., 2009). In this study, blood lactate concentrations were significantly lower in all TOE treated groups than in the normal control (NC) group $(\mathrm{p}<0.05)$. Therefore, it can thus be considered that TOE could effectively retard and lower the blood lactate produced after exercise, postpone the appearance of physical fatigue and accelerate the recovering from physical fatigue.

Table 1: Effect of TOE on the blood biochemical parameters

\begin{tabular}{|l|l|l|l|}
\hline Group & Triglyceride $(\mathrm{mg} / \mathrm{dL})$ & Glucose $(\mathrm{mg} / \mathrm{dL})$ & Lactate $(\mathrm{mg} / \mathrm{dL})$ \\
\hline Normal control (NC) & $168.23 \pm 14.84$ & $56.24 \pm 14.48$ & $70.28 \pm 3.76$ \\
\hline Low-dose (LD) & $121.35 \pm 18.78^{\mathrm{a}}$ & $94.26 \pm 17.97^{\mathrm{a}}$ & $54.27 \pm 6.43^{\mathrm{a}}$ \\
\hline Middle-dose (MD) & $114.72 \pm 11.42^{\mathrm{a}}$ & $87.29 \pm 21.37^{\mathrm{a}}$ & $52.61 \pm 4.75^{\mathrm{a}}$ \\
\hline High-dose (HD) & $106.89 \pm 19.36^{\mathrm{a}}$ & $81.27 \pm 19.65^{\mathrm{a}}$ & $47.23 \pm 5.77^{\mathrm{a}}$ \\
\hline
\end{tabular}

Each value represents mean $\pm \mathrm{SD} ; \mathrm{n}=10{ }^{\mathrm{a}} \mathrm{p}<0.05$, compared with normal control group 


\section{Conclusion}

The present results suggested that TOE showed an anti- physical fatigue effect. It enhanced the maximum swimming capacity of mice, effectively delayed the lowering of glucose in the blood, and prevented the increase in lactate and triglyceride concentrations.

\section{References}

1. Abe, T., Takiguchi, Y., Tamura, M., Shimura, J. and Yamazaki, KI. (1995). Effect of vespa amino acid mixture (VAAM) isolated from hornet larval saliva and modified VMM nutrients on endurance exercise in swimming mice improvement in performance and changes of blood lactate and glucose. Jpn J Physiol Fitness Sports Med, 44: 225-238.

2. Babcock, MA., Johnson, BD., Pegelow, DF., Suman, OE., Griffin, D. and Dempsey, JA.(1995). Hypoxic effects on exercise-induced diaphragmatic fatigue in normal healthy humans. J Appl Physiol, 78: 82-92.

3. Borer, KT., Wuorinen, EC., Lukos, JR., Denver, JW., Porges, SW. and Burant, CF. (2009). Two bouts of exercise before meals, but not after meals, lower fasting blood glucose. Med Sci Sports Exerc, 41: 1606-1614.

4. Cao, SH., Shang, HP., Wu, WB., Du, JR. and Putheti, R. (2009). Evaluation of anti-athletic fatigue activity of Schizandra chinensis aqueous extracts in mice. African Journal of Pharmacy and Pharmacology, 3: 593-597.

5. Fueger, PT., Li, CY., Ayala, JE., Shearer, J., Bracy, DP., Charron, MJ., Rottman, JN. and Wasserman, DH. (2007). Glucose kinetics and exercise tolerance in mice lacking the GLUT4 glucose transporter. J Physiol, 582: 801-812.

6. Grandjean, E.P. (1970). F Fatigue. Am. Ind. Hyg. Assoc. J, 31: 401-411.

7. Hu, C. and Kitts, DD. (2003). Antioxidant, prooxidant, and cytotoxic activities of solvent-fractionated dandelion (Taraxacum officinale) flower extracts in vitro. J Agric Food Chem, 51: 301-310.

8. Jeon, HJ., Kang, HJ., Jung, HJ., Kang, YS., Lim, CJ., Kim, YM. and Park, EH. (2008). Anti-inflammatory activity of Taraxacum officinale. J Ethnopharmacol, 115: 82-88.

9. Jones, NL. and Havel, RJ. (1967). Metabolism of free fatty acids and chylomicron triglycerides during exercise in rats. American Journal of Physiology, 213: 824-828.

10. Jung, K., Kim, I. and Han, D. (2004). Effect of medicinal plant extracts on forced swimming capacity in mice. Journal of Ethnopharmacology. 93: 75-81

11. Kim, HM., Shin, HY., Lim, KH., Ryu, ST., Shin, TY, Chae, HJ., Kim, HR., Lyu, YS., An, NH. and Lim, KS. (2000). Taraxacum officinale inhibits tumor necrosis factor-alpha production from rat astrocytes. Immunopharmacol Immunotoxicol, 22: 519-530.

12. Koo, HN., Hong, SH., Song, BK., Kim, CH., Yoo, YH. and Kim, HM. (2004). Taraxacum officinale induces cytotoxicity through TNF-alpha and IL-1alpha secretion in Hep G2 cells. Life Sci, 74: 1149-1157.

13. Kramer, K., Dijkstra, H. and Bast, A. (1993). Control of physical exercise of rats in a swimming basin. Physiol Behav, 53: 271-276.

14. Lin, Y. and Zheng, JH. (1998). Research progress of a Chinese traditional drug taraxacum herb. The Chinese Journal of Modern Applied Pharmacy, 15: 42-47.

15. Ling Y., Shan J., Zhang YL. and Zhang YL. (2005). Effects of Dandelions on proliferation of spleen Lymphocytes in Mice. Pharmaceutical Journal of Chinese People s Liberation Army, 25(1): 73-74.

16. Nozawa, Y., Yamada, K., Okabe, Y., Ishizaki, T. and Kuroda, M. (2009). The anti-fatigue effects of the low-molecular-weight fraction of bonito extract in mice. Biol Pharm Bull. 32(3): 468-474.

17. Ream, E. and Richardson, A. (1997). Fatigue in patients with cancer and chronic obstructive airways disease: a phenomenological enquiry. J. Nurs. Stud, 34: 44-53.

18. Schütz, K., Kammerer, DR., Carle, R. and Schieber, A. (2005). Characterization of phenolic acids and flavonoids in 
dandelion (Taraxacum officinale WEB. ex WIGG.) root and herb by high-performance liquid chromatography/electrospray ionization mass spectrometry. Rapid Commun Mass Spectrom, 19: 179-186.

19. Seo, SW., Koo, HN., An, HJ., Kwon, KB., Lim, BC., Seo, EA., Ryu, DG., Moon, G., Kim, HY., Kim, HM. and Hong, SH. (2005). Taraxacum officinale protects against cholecystokinin-induced acute pancreatitis in rats. World J Gastroenterol, 11: $597-599$.

20. Shen, Q., Gu, GP., Wu, GR. and Zhang, WM. (2004). Study on the Progress of the Dandelion. The Chinese Academic Medical Magazine of Organisms, 2: 6-7.

21. Shen, Q., Zhao, HM., Zhang, WM., Lu, CM. and Wu, GR. (2006). Study on Extraction and Separation Technology of Chlorogenic Acid in Dandelion. Food Science, 27: 140-144.

22. Shin, HY., Jeong, HJ., Hyo, JA., Hong, SH., Um, JY., Shin, TY., Kwon, SJ., Jee, SY., Seo, BI., Shin, SS., Yang, DC. and Kim, HM. (2006). The effect of Panax ginseng on forced immobility time \& immune function in mice. Indian J Med Res, 124: 199-206.

23. Sigstedt, SC., Hooten, CJ., Callewaert, MC., Jenkins, AR., Romero, AE., Pullin, MJ., Kornienko, A., Lowrey, TK., Slambrouck, SV. and Steelant, WF. (2008). Evaluation of aqueous extracts of Taraxacum officinale on growth and invasion of breast and prostate cancer cells. Int J Oncol, 32: 1085-1090.

24. Su, SH., Jin, YP., Qin, XX. and Song, YM. (2008). Main Medical Effect of the Extracts from Herba taraxaci and Total Flavones in Chamaejasmine. Acta Agriculturae Boreali-Occidentalis Sinica, (4): 181-185.

25. Sugino, T., Aoyagi, S., Shirai, T., Kajimoto, Y. and Kajimoto, O. (2007). Effects of Citric Acid and L-Carnitine on Physical Fatigue. J Clin Biochem Nutr, 41(3): 224-230.

26. Van der Vusse, PB. and Saris, CJ. (1991). Carbohydrate supplementation glycogen depletion and amino acid metabolism during exercise. Am J Physiol, 260: 883-890.

27. Wang, JJ., Shieh, MJ., Kuo, SL., Lee, CL. and Pan, TM. (2006). Effect of red mold rice on antifatigue and exercise-related changes in lipid peroxidation in endurance exercise. Appl Microbiol Biotechnol, 70: 247-253.

28. Williams, CA., Goldstone, F. and Greeham, J. (2008). Flavonoids, cinnamic acids and coumarins from the different tissues and medicinal preparations of Taraxacum officinale. Phytochemistry, 42: 121-127.

29. Wu, XL., Cai, YQ., Zhao, Y. and Li, SF. (2005). Effects of extract from taraxacum monogon(ETM) on immune modulation in mice. Acta Academiae Medicinae Nanjing, 25(3): 163-165.

30. Xu, HT. and Xu, YJ. (2008). Simultaneous Determination of Three Phenolic Acid in Pugongying Granules by High Performance Liquid Chromatography-Mass Spectrometry. Chemistry, 71: 1-6.

31. Yalcin, O., Bor-Kucukatay, M., Senturk, UK, and Baskurt, OK. (2000). Effects of swimming exercise on red blood cell rheology in trained and untrained rats. J Appl Physiol, 88: 2074-2080.

32. Yu, B., Lu, ZX., Bie, XM., Lu, FX. and Huang, XQ. (2008). Scavenging and antifatigue activity of fermented defatted soybean peptides. Eur Food Res. Technol, 226:415-421.

33. Zhang, J., Kang, MJ., Kim, MJ., Kim, ME., Song, JH., Lee, YM. and Kim, JI. (2008). Pancreatic lipase inhibitory activity of taraxacum officinale in vitro and in vivo. Nutr Res Pract, 2: 200-203.

34. Zinker, BA., Dalliman, PR. and Brooks, GA. (1993). Augumented glucoregulatory hormone concentrations during exhausting exercise in middly iron-deficient rats. Am. J. Physiol, 265: R 863-R 871. 